\title{
Parents and television advertisements as consumer socialisation agents for adolescents: An exploratory study
}

\author{
Ernest J North and Theuns Kotzé
}

\begin{abstract}
OPSOMMING
Weinig navorsing oor die rol en invloed van sosialiseringsagente op die verbruikersgedrag van kinders is tot op hede in Suid Afrika onderneem. Alhoewel bemarkers bewus is van die potensiële koopkrag van kinders en veral wat hul invloed op verbruikersbesluitneming in die gesin is, blyk dit dat hulle nog nie die jeugmark as 'n volwaardige mark beskou wat navorsing regverdig nie. Die doel van hierdie artikel is om die bevindinge van ' $n$ empiriese ondersoek oor die rol wat ouers en televisie-advertensies in die verbruikersosialisering van kinders speel, weer te gee.
\end{abstract}

Die gebrek aan plaaslike navorsing op hierdie terrein het ' $n$ uitgebreide literatuurstudie vereis wat as teoretiese fundering kon dien om die aard en prosesse van die verbruikersosialisering van kinders te beskryf. Die primêre data vir die navorsing is verkry deur ' $n$ vraelysopname wat deur 226 hoërskoolleerlinge voltooi is.

Die bevindinge van die studie toon dat die ouers ' $n$ baie belangrike sosialiseringsagent in die verbruikersopleiding van kinders is. Jong adolessente besef dat hul ouers se opinies en leiding rondom die moontlike invloede van televisie-advertensies op hul aankoopbesluite nie onderskat kan word nie. Die studie onderstreep die behoefte daaraan om meer navorsing ter plaatse in die veld te doen. Benewens die ouers en die media, behoort navorsing ook oor die rol wat ander sosialiseringsagente soos die skool en verkoopspersoneel in die verbruikersopvoeding van kinders speel, onderneem te word.

- Dr Ernest J. North

- Mr Theuns Kotzé

Department of Marketing and Communication Management, University of Pretoria

\section{INTRODUCTION}

Children are consumers in their own right. Market research shows that children wield considerable power as consumers, and their influence on family purchases goes beyond the selection of toys and cereals. According to McNeal, the typical child in the United States is exposed to some 20000 advertisements a year, and these young consumers (between the age of four and 12) spent almost $\$ 25$ billion of their own money in 1998 (Geary, 1999). They also exert a substantial influence on their parents' consumer decision making and spending (Hawkins et al., 2001:207). Blackwell et al. (2001:748) state that adolescent influence on household spending varies by product user and by degree. They have a greater influence in decisions on purchases of products for their own use. In South Africa there are approximately 12,9 million school-going children of whom the $35 \%$ in secondary school command a disposable income of R4 billion per/year (Mulrooney, 1999). According to Koenderman (2001), children (of all ages) spend R4,5 billion/year in South Africa and influence the spending of another R20 billion/year including the purchase of items such as television sets and cars.

Scholarly research examining the consumer behaviour of children dates back to the 1950s. Although much has been said and written about the development of children as consumers, not all of this material is based on solid research. The lack of systematic research on the consumer behaviour of children, and specifically the influence or role of consumer socialisation agents (such as parents, retailers and the school), can possibly be ascribed to the fact that marketers may think that it is inappropriate to regard children as a "market" (McNeal in Stipp, 1988).

The effects of advertising (and the role of the mass media as a socialisation agent) on children have, however, been the subject of considerable research during the past three decades (Meyer, 1987; Roedder, 1981; Macklin, 1987; Yavas \& Abdul-Gader, 1993; CardwellGardner \& Bennett, 1999). The findings of a recent study by Carlson et al. (2001) indicate that parental styles play a role in determining the manner in which mothers socialise their children about television and television advertising. Children are difficult to study, and today's children live in a rapidly changing technological world. McGee (1997:53) is of the opinion that research with children is "... an even newer idea than selling things to them". Research must therefore be undertaken to understand the consumer behaviour of 
children, and to ascertain the reasons why they feel and act the way they do.

In the South African context, a limited number of studies have so far investigated the consumer behaviour of children. These studies include focus groups with children to determine, inter alia, how children identify with child actors in magazine and television advertisements (North, 1987) and assess their understanding of television advertisements (Cardwell-Gardner \& Bennett, 1999). A literature study in the fields of marketing and the consumer sciences revealed that not a single study has so far investigated the consumer socialisation of children in South Africa. The question arises whether marketers are taking note of current changes in the social environment, and whether this is reflected in their marketing strategies. Marketers in South Africa are being challenged to adapt their marketing and advertising strategies to fit in with the new environment created by post-apartheid changes. The limited number of studies of the consumer behaviour of children and the relevance of this topic to South African marketers and consumer scientists suggest the need for further research.

The purpose of this article is to report the findings of an exploratory study conducted to investigate the role of parents and television advertisements as consumer socialisation agents for children. A broad overview will be provided of the nature and processes of consumer socialisation and the research conducted in this field during the past few decades. A number of important marketing implications will also be discussed.

\section{BACKGROUND AND HISTORICAL OVERVIEW}

\section{Consumer socialisation}

Children move through various cognitive and social phases on their journey from birth to adolescence and adulthood. Consumer socialisation (which is only a part of a child's general socialisation) is described as "the processes by which young people acquire skills, knowledge, and attitudes relevant to their functioning as consumers in the marketplace" (Ward, 1974:2). Although McNeal (1993) sometimes refers to it as "consumer education" or "consumer development", Ward's description of the concept can be regarded as a universally accepted definition (McGregor, 1999; John, 1999; Carlson \& Grossbart, 1994). John (1999) views consumer socialisation as a process that occurs in the context of social and cognitive development as children move through three stages of consumer socialisation, namely the perceptual stage (3-7 years), the analytical stage (7-11 years), and the reflective stage (11-16 years). This latter stage, which is particularly relevant for this study, is characterised by the development of information processing skills (such as interpreting advertising messages) and social skills. Children pay more attention to the social aspects of being a consumer (John, 1999). In this stage adolescents' knowledge about branding becomes extremely important. Acceptance by the peer group is often guaranteed when a teenager wears the "right" brand of
T-shirt or jeans. According to Acuff (1997:106), peers play an enormous role when teenagers have to make buying decisions in this early adolescent stage. These early teenagers are also very activity oriented, for example taking part in organised sport, playing computer games, viewing television programmes, engaging in various school activities and shopping (Acuff, 1997:107, 110).

Blackwell et al. (2001:387) are of the opinion that children learn their consumer skills primarily from shopping with parents - a phenomenon these authors call "coshopping." Co-shoppers tend to be more concerned with their children's development as consumers and they "... explain more to their children why they don't buy products", which to some extent "...may mediate the role of advertising." (Blackwell et al., 2001:387). McNeal (1993) states that children pass through the following five-stage shopping learning process in their consumer development:

Stage 1: Observing This first stage is the child's initial interaction with the marketplace. Mothers usually take their infants to shopping malls and stores where they make sensory contact with the shopping environment. McNeal's (1993) studies show that the median age here was two months, but answers ranged from one to 33 months. As stated earlier, John's framework or three stages of consumer socialisation starts at the perceptual stage (36 months - 7 years).

\section{Stage 2: Making requests During this phase, (which corresponds partly with John's perceptual stage), children make requests (by pointing, gesturing and even making statements) to parents when they see something they want in the store. In the latter part of this phase they make requests for specific products at home, probably because of the stimulation by tele- vision advertisements.}

Stage 3: Making selections When children start walking (3-4 years of age - partly in John's perceptual stage), they experience their first physical contact as consumers by choosing an article and taking it from the shelf.

Stage 4: Assisted purchases Almost from birth, children regularly witness their parents and other shoppers giving money in exchange for goods. These scenes give meaning to the money children receive from their parents or grandparents. During this stage (the latter part of John's perceptual stage and the early part of the analytical stage, 7-11 years) children start spending money on their own. This contributes to the child's understanding that the store owns the goods and money is the medium of exchange.

Stage 5: Making independent purchases The fifth and final step in the development of consumer behaviour is performing independent purchases without parental assistance (John's reflective stage, 11-16 years). There is usually a significant time lag between a child's first purchase with parents and an independ- 
ent purchase (McNeal \& Yeh, 1993). Acuff (1997:109) reports on the findings of a study that found that teenagers do not consult their parents for buying candy and soft drinks in 92 percent of the cases. In 70 percent of the cases clothes are purchased independently and in only 20 percent of the cases do they not consult their parents when computer software is purchased.

According to Sheth et al. (1999:587) consumer socialisation occurs when one or more of the following are learned or acquired by children: "... preferences among alternative brands and products; knowledge about product features and the functioning of the marketplace; and skills in making 'smart decisions'..." The theory and published literature focus largely on consumer socialisation in the childhood phase. McGregor (1999) and Engel et al. (1995:613) emphasise, however, that it should be recognised as a lifelong process.

Recent studies by consumer scientists examined other areas of consumer socialisation, such as the socialisation of consumers in a global marketplace, and the protection of consumers in the electronic marketplace (McGregor, 1999); consumer complaint behaviour in the children's wear market (Norum \& Scrogin, 1996); and the factors that influence the food choices of children between the ages of 9 and 17 years (Hamilton et al, 2000). No attention was given to the role of the media and parents as socialisation agents in these latter studies.

McNeal (1973:9) summarises the value of and the reason for the need to study the consumer socialisation of children as follows: "Much consumer behaviour is performed under the influence of others. The very foundation of human behaviour is learning from others." McGregor (1999) states that consumer socialisation is a function of, inter alia, the age of the child, the content that is learned, and agents of socialisation.

\section{Consumer socialisation agents}

The learning of consumer behaviour patterns (consumer socialisation) by children has been of interest to researchers since the end of World War 2. In the 1950s and 1960s, pioneers like Guest, McNeal, Berey and Pollay (John, 1999) began to examine factors related to the consumer behaviour of children. The topics investigated include children's understanding of marketing and retail functions, brand loyalty and the influence of children in family decision making. No specific study of the influence of consumer socialisation agents on children's buying behaviour has been reported in these early years of research. Socialisation agents are the persons and organisations involved in the orientation and education of children as consumers. Some examples would be family members, peers, the mass media, schools and retailers (John, 1999).

Research in the field of the consumer socialisation process of children gained momentum in the mid- 1970s (John, 1999). Scott Ward's (1974) article entitled "Consumer socialisation" which was published in the Journal of Consumer Research, forcefully argued for studying children and their socialisation into the consumer role. This gave a lead to a new generation of researchers, and in particular directed their attention to the role of socialisation agents in children's development as consumers. Of particular importance to this review are the studies that focused on children's knowledge of consumer issues, and the influence of the family and the media (as socialisation agents) on children's development as consumers.

The family can be regarded as the primary source (agent) of consumer socialisation. Extensive research has been conducted on the role of the family as a consumer socialisation agent over the past three decades (John, 1999; Carlson \& Grossbart, 1994; Hempel, 1974). Hawkins et al. (2001:212, 213) state that parents teach their children consumer skills both deliberately and casually through instrumental training, modelling and mediation. Instrumental training occurs, for example, when a parent tries to teach a child to eat a certain snack because it has nutritional value. Modelling occurs when a child learns appropriate (or inappropriate) consumption behaviours by observing others (for example parents who smoke). Mediation occurs when a parent alters a child's initial interpretation of or response to a marketing stimulus (for example an advertisement depicting a situation in which a child will be rewarded with a snack for good behaviour).

The main objective of this study was to determine the role or influence of the parents and television advertisements as consumer socialisation agents for young adolescents. Special emphasis is placed on children's perceptions of the influence of television advertisements on their buying behaviour, and the extent to which their parents use television advertisements as an opportunity for consumer education.

\section{METHOD}

\section{Sampling}

A list of secondary schools in the north-eastern area of Pretoria served as the basis for the sampling procedure. A non-probability convenience sample resulted in the selection of five secondary schools which represented a balanced blend of language, gender and ethnic diversity (schools that have open policies regarding the admission of children). The three cognitive stages of consumer socialisation (perceptual, analytical and reflective stages) as described by John (1999), and the basic age-related criteria when marketing messages for children are planned (Acuff 1997:14) formed the basis on which researchers selected the specific age group to include in the sample. It was decided to involve 250 grade 8 and 9 pupils (50 pupils per school) in the survey (children in the reflective stage, 11-16 years). The researcher assumed that children in this age group, who come from families in the middle to higher income groups, have access to 


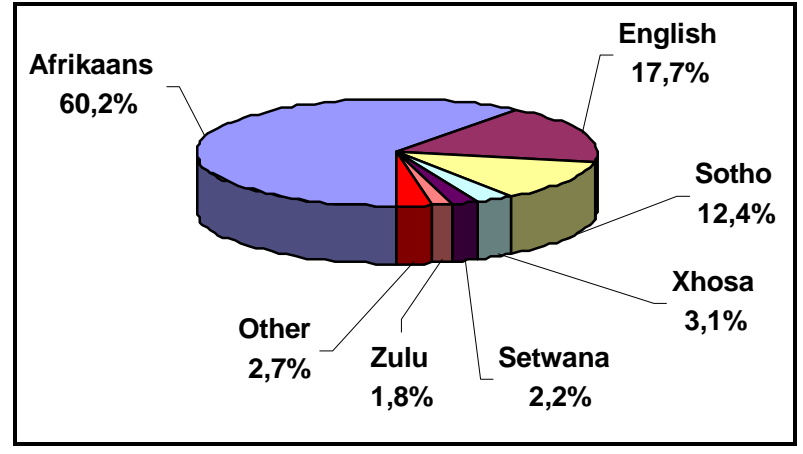

FIGURE 1: LANGUAGE OF RESPONDENTS IN SAMPLE ( $\mathrm{N}=226)$

television and have had many experiences of buying products and making buying decisions either with or without their parents' help or intervention.

\section{Research instrument}

A five-point Likert scale questionnaire comprising 26 questions was distributed to the 250 secondary school children. The items in the scale are based on a scale that was used in a research project to determine mothers' perceptions of the influence of television advertising on their children (Elliot, 2000). A literature study in the fields of marketing to children, advertising and marketing communication served as basis for the compilation of Elliot's scale. According to Burns and Bush (1998:297) the value of the Likert scale format lies in the fact that respondents are asked to indicate how much they agree or disagree with the statement. In this survey respondents were asked to indicate to what extent they agree or disagree with statements regarding the possible influence of television advertising on their buying behaviour, and to what extent they believe their parents use television advertisements to influence their buying behaviour. The scale therefore captures the intensity of their feelings toward television advertisements. Cooper and Schindler (1998:189) refers to this type of scale as a summated rating scale where each response "...is given a numerical score to reflect its attitude favorableness..."

Care was taken to ensure that the measuring instrument complied with the prerequisites of validity and reliability. De Vos (1998:83) states that a valid instrument actually measures the concept in question, and the concept is measured accurately. The content validity of the questionnaire was established by asking colleagues and post-graduate students in the field of marketing to assess the instrument. According to De Vos (1998:85), the most difficult approach to validation is construct validity: "It is a lengthy, painstaking process, much like theory construction...". As this study is of an exploratory nature, this topic will be left at that. Burns and Bush (1998:308) and Cooper and Schindler (1998:171) refer to various methods of assessing reliability (the degree that a measure supplies consistent results), such as test-retest, split-half reliability and Cronbach's alpha. The latter is particularly useful in indicating the degree to which instrument items are homogeneous and reflect the same underlying construct(s).

\section{Data collection}

The principals or designated teachers at the five schools were requested to distribute the questionnaires to grade eight and nine pupils at the school. The teachers were specifically requested to take care that both genders and pupils from a variety of cultural backgrounds were given the opportunity to complete the questionnaire. A very satisfactory response rate of 90 percent was obtained, most probably because the teachers requested the pupils to complete the questionnaires in class and return them immediately. A breakdown of the language composition appears in Figure $1(n=226)$. A summary of the information in Figure 1 indicates that 60 percent of the respondents completed the questionnaire in Afrikaans and the remainder completed it in English. The 2,7\% respondents included under "Other languages" include Tsonga, Chinese, Portuguese, Seswati and Swazi speaking pupils.

\section{Descriptive statistics and reliability results}

Data for the study were collected from a convenience sample of 226 secondary school children (37,7\% male, $63,3 \%$ female with a mean age: 13,55 years) using a self-completion questionnaire. The questionnaire consisted of 26 Likert scale items as well as demographic questions on respondents' age, gender and home language. Respondents had the option to register a "don't know" to all 26 Likert scale items. The items were subjected to item analysis based on the recommendations offered by Nunnally (1978: 279282). Based on these recommendations and using a cut-off item-to-total correlation value of $>0,20$, nine items were removed (see Table 1 for the item-to-total correlations of the remaining items). Cronbach's alpha was calculated for the remaining items and an alpha coefficient of 0,785 was obtained which is satisfactory for an exploratory study (Nunnally 1978: 245).

The remaining 17 items were next subjected to a principal components analysis with varimax rotation (the eigenvalue $>1$ criteria was used as the cut-off rule for factor extraction). Respondents with missing or "don't know" responses were excluded from the factor analysis, resulting in the responses of 121 respondents being analysed. The factor analysis resulted in a fivefactor solution explaining $54 \%$ of the cumulative variance (see Table 2). Two items cross-loaded significantly (factor loadings $>0,4$ ) on more than one factor. These two items were deleted (Hair et al., 1998: 113). The cross-loadings, together with difficulties in conceptually interpreting some of the factors and the fact that two of the items included in the analysis generated a relatively high percentage of "don't know" responses, suggest a need for further refinement of the scale items used.

Problems were also experienced in the interpretation of the factor solution in Table 2 . In the light of the ex- 
TABLE 1: ITEM-TO-TOTAL CORRELATIONS OF SCALE ITEMS

\begin{tabular}{|l|l|c|}
\hline Item & \multicolumn{1}{|c|}{ Statement } & $\begin{array}{c}\text { Item-to-total } \\
\text { correlation }\end{array}$ \\
\hline Q 4 & I often want products seen in a TV ad & 0,399 \\
\hline Q 5 & Products are as good as expected from TV ads & 0,359 \\
\hline Q 6 & My parents recommend a TV advertised product for my own good & 0,427 \\
\hline Q 7 & My parents recommend a TV advertised product because they believe I'll like it & 0,542 \\
\hline Q 8 & My parents recommend a TV advertised product so I can try it & 0,549 \\
\hline Q 9 & My parents recommend a product seen on TV because I want it & 0,461 \\
\hline Q 10 & My parents recommend a TV advertised product for their own good & 0,378 \\
\hline Q 11 & I know why my parents recommend a TV advertised product & 0,419 \\
\hline Q 12 & I often want products recommended by my parents & 0,310 \\
\hline Q 13 & TV ads will say when a product is not good & 0,344 \\
\hline Q 17 & If a TV ad says a product is good and my parents say it is not & 0,345 \\
\hline Q 18 & TV ads help me find the best products & 0,380 \\
\hline Q 21 & TV ads stimulate me to want heavily advertised products more than those products not as & 0,233 \\
\hline Q 22 & I engage in behaviours to buy TV advertised products & 0,330 \\
\hline Q 23 & The more frequently I ask for a product the more my parents believe I have seen it on TV & 0,268 \\
\hline Q 24 & I watch TV with my parents & 0,252 \\
\hline Q 25 & I enjoy TV ads & 0,344 \\
\hline
\end{tabular}

ploratory nature of the study, it was therefore decided to continue the discussion based on the following broad issues (as indicated in Table 3):

- children's perceptions of the effect of television advertising on their buying decisions

- how parents use television advertisements for the consumer socialisation of children

- children's perceptions on the value of their parents' efforts to use television advertisements to make a positive contribution to their consumer socialisation.

\section{RESULTS AND DISCUSSION}

Table 3 provides the mean values, standard deviations, two-top and two-low box scores and the percentage of "don't know" responses for the 17 remaining items in the scale. The two-top and two-low box scores indicate the percentage of respondents who marked the two highest, that is 4 (agree) and 5 (strongly agree) and the two lowest, that is 1 (strongly disagree) and 2 (disagree) scale points respectively. For discussion purposes the 17 items (statements in the questionnaire) were grouped together under three sub-headings as indicated in Table 3 below.

\section{Children's perceptions of the effect of television advertising on their buying decisions}

The data in Table 3 indicate that television advertisements definitely have an influence on the buying decisions of teenagers. More than 50 percent said they often want products seen in a TV advertisement (Q04). Almost one-third of the respondents said they want a product advertised on television even if their parents say it is not good (Q17). These findings are in agreement with many studies conducted in this field within the past decade or two (Yavas \& Abdul-Gader, 1993; Gorn \& Forsheim, 1985; Roedder, 1981). A study done in Europe found, however, that "... television advertising does not cause children to pester their parents." According to John (1999), teenagers are sceptical about advertising when they are in the reflective stage. They do, however, use a variety of information sources (including television advertisements) for consumer decision making purposes. It was not the intention of this study to examine which television advertised products children would like to buy, but Isler et al. (1987:33) found that snack foods $(24 \%)$ and clothes (17\%) are the two product types requested mostly by older children. More than onethird of the repondents in this study are of the opinion that they want to buy products that are heavily advertised rather than those that are not heavily advertised (Q21). Almost 25 percent of the children in the sample agree or strongly agree that television advertisements help them to find the best product (Q18). When it comes to actually buying the advertised product (Q22), almost 18 percent indicated that they engage 
TABLE 2:

FACTOR STRUCTURE AND LOADINGS

\begin{tabular}{|l|l|l|l|l|l|l|}
\hline Item & Statement & $\begin{array}{c}\text { Factor 1 } \\
\text { Reasons for } \\
\text { parental re- } \\
\text { commendation }\end{array}$ & $\begin{array}{c}\text { Factor 2 } \\
\text { Positive } \\
\text { impact of } \\
\text { TV ads }\end{array}$ & $\begin{array}{c}\text { Factor 3 } \\
\text { Asking for } \\
\text { products } \\
\text { seen on TV }\end{array}$ & $\begin{array}{c}\text { Factor 4 } \\
\text { Wanting } \\
\text { advertised } \\
\text { products }\end{array}$ & $\begin{array}{c}\text { Factor 5 } \\
\text { Wanting } \\
\text { recommended } \\
\text { products }\end{array}$ \\
\hline Q 4 & I often want products seen in a TV ad & & & & 0,7518 & \\
\hline Q 5 & $\begin{array}{l}\text { Products are as good as expected } \\
\text { from TV ads }\end{array}$ & 0,4446 & & & & \\
\hline Q 6 & $\begin{array}{l}\text { My parents recommend a TV adver- } \\
\text { tised product for my own good }\end{array}$ & 0,6950 & & & & \\
\hline Q 7 & $\begin{array}{l}\text { My parents recommend a TV adver- } \\
\text { tised product because they believe I'll } \\
\text { like it }\end{array}$ & 0,6333 & & & & \\
\hline Q 8 & $\begin{array}{l}\text { My parents recommend a TV adver- } \\
\text { tised product so I can try it }\end{array}$ & 0,6135 & & & & \\
\hline Q 10 & $\begin{array}{l}\text { My parents recommend a TV adver- } \\
\text { tised product for their own good }\end{array}$ & 0,6021 & & & & \\
\hline Q 11 & $\begin{array}{l}\text { I know why my parents recommend a } \\
\text { TV advertised product }\end{array}$ & & & & & \\
\hline Q 12 & $\begin{array}{l}\text { I often want products recommended } \\
\text { by my parents }\end{array}$ & & & & & \\
\hline Q 13 & $\begin{array}{l}\text { TV ads will say when a product is not } \\
\text { good }\end{array}$ & & 0,5880 & & & \\
\hline Q 17 & $\begin{array}{l}\text { If a TV ad says a product is good and } \\
\text { my parents say it is not }\end{array}$ & & & & & \\
\hline Q 18 & $\begin{array}{l}\text { TV ads help me find the best prod- } \\
\text { ucts }\end{array}$ & & 0,6522 & & & \\
\hline Q 22 & $\begin{array}{l}\text { I engage in behaviours to buy TV ad- } \\
\text { vertised products }\end{array}$ & & & & & \\
\hline Q 23 & $\begin{array}{l}\text { The more frequently I ask for a prod- } \\
\text { uct the more my parents believe I } \\
\text { have seen it on TV }\end{array}$ & & & & & \\
\hline Q 24 & I watch TV with my parents & 0,5704 & & & \\
\hline Q 25 & I enjoy TV ads & & & & \\
\hline
\end{tabular}

in behaviours to buy the product, whereas 36 percent do not intend to buy products advertised on television.

\section{How parents use television advertisements for the consumer socialisation of children}

Almost 60 percent of the children in the sample said they spend quite a lot of time watching television with their parents. Only 19 percent said they do not watch television with their parents (Q24). When children watch television with their parents, communication and evaluation of advertisements will naturally occur. Blackwell et al. (2001:387) considers family communication about purchases as the key to children's consumer socialisation. When children need information on new products, the findings of a study by McNeal and $\mathrm{Ji}$ (1999) indicate that television and parents ranked the highest among Chinese children. Parents can use television advertisements in various ways as a means of communicating and educating their children in consumer matters. The brand preferences of parents for certain products, for example, can influence their children's brand choices when specific brand items are televised (Hogg, Bruce \& Hill in Blackwell et al., 2001:386). According to John (1999), the reflective stage of consumer socialisation is characterised by an understanding of branding and a substantial brand awareness by teenagers for adultoriented products. In this study, children were asked to indicate why they think their parents recommend products to them that are advertised on television. Although this aspect was not specifically examined in this study, it is assumed that many parents recommend the brands they prefer to their children. Although the majority of the respondents indicated that 
TABLE 3: $\quad$ AVERAGED ITEM RESPONSES

\begin{tabular}{|c|c|c|c|c|c|c|}
\hline Item & Statement & Average & $\begin{array}{l}\text { Standard } \\
\text { Deviation }\end{array}$ & $\begin{array}{l}\text { Two-low } \\
\text { box }\end{array}$ & $\begin{array}{l}\text { Two-top } \\
\text { box }\end{array}$ & $\begin{array}{l}\text { Count } \\
\% \text { DK }\end{array}$ \\
\hline \multicolumn{7}{|c|}{ Effect of television advertisements on buying decisions } \\
\hline Q 4 & I often want products seen in a TV ad & 3,54 & 1,26 & $19,5 \%$ & $50,9 \%$ & $0,5 \%$ \\
\hline Q 5 & Products are as good as expected from TV ads & 2,24 & 1,20 & $56,3 \%$ & $13,5 \%$ & $5,4 \%$ \\
\hline Q 17 & $\begin{array}{l}\text { If a TV ad says a product is good and my parents say } \\
\text { it is not }\end{array}$ & 2,93 & 1,40 & $36,3 \%$ & $31,4 \%$ & $5,8 \%$ \\
\hline Q 18 & TV ads help me find the best products & 2,84 & 1,23 & $38,6 \%$ & $27,4 \%$ & $3,6 \%$ \\
\hline Q 21 & $\begin{array}{l}\text { TV ads stimulate me to want heavily advertised prod- } \\
\text { ucts more than those products not as heavily adver- } \\
\text { tised }\end{array}$ & 3,07 & 1,33 & $28,7 \%$ & $34,1 \%$ & $7,2 \%$ \\
\hline Q 22 & $\begin{array}{l}\text { I engage in behaviours to buy TV advertised prod- } \\
\text { ucts }\end{array}$ & 2,67 & 1,16 & $36,5 \%$ & $17,8 \%$ & $13,7 \%$ \\
\hline Q 23 & $\begin{array}{l}\text { The more frequently I ask for a product the more my } \\
\text { parents believe I have seen it on TV }\end{array}$ & 3,15 & 1,44 & $33,8 \%$ & $43,6 \%$ & $4,4 \%$ \\
\hline Q 25 & I enjoy TV ads & 2,65 & 1,56 & $50,0 \%$ & $30,5 \%$ & $1,3 \%$ \\
\hline \multicolumn{7}{|c|}{ How parents use advertisements for consumer socialisation } \\
\hline Q 6 & $\begin{array}{l}\text { My parents recommend a TV advertised product for } \\
\text { my own good }\end{array}$ & 2,46 & 1,22 & $50,0 \%$ & $18,8 \%$ & $5,4 \%$ \\
\hline Q 7 & $\begin{array}{l}\text { My parents recommend a TV advertised product be- } \\
\text { cause they believe l'll like it }\end{array}$ & 2,70 & 1,32 & $42,5 \%$ & $25,2 \%$ & $6,2 \%$ \\
\hline Q 8 & $\begin{array}{l}\text { My parents recommend a TV advertised product so I } \\
\text { can try it }\end{array}$ & 2,40 & 1,38 & $55,8 \%$ & $23,2 \%$ & $5,4 \%$ \\
\hline Q9 & $\begin{array}{l}\text { My parents recommend a product seen on TV be- } \\
\text { cause I want it }\end{array}$ & 2,82 & 1,34 & $40,8 \%$ & $29,6 \%$ & $4,9 \%$ \\
\hline Q 10 & $\begin{array}{l}\text { My parents recommend a TV advertised product for } \\
\text { their own good }\end{array}$ & 2,54 & 1,30 & $48,0 \%$ & $24,7 \%$ & $8,1 \%$ \\
\hline Q 24 & I watch TV with my parents & 3,67 & 1,33 & $18,6 \%$ & $58,8 \%$ & $1,3 \%$ \\
\hline \multicolumn{7}{|c|}{ Children's perceptions of the value of advertisements for consumer socialisation } \\
\hline Q 11 & $\begin{array}{l}\text { I know why my parents recommend a TV advertised } \\
\text { product }\end{array}$ & 2,82 & 1,43 & $36,9 \%$ & $26,7 \%$ & $18,2 \%$ \\
\hline Q 12 & I often want products recommended by my parents & 2,77 & 1,41 & $45, \& \%$ & $30,9 \%$ & $4,0 \%$ \\
\hline Q 13 & TV ads will say when a product is not good & 1,64 & 1,24 & $76,7 \%$ & $12,1 \%$ & $5,4 \%$ \\
\hline
\end{tabular}

their parents do not recommend products advertised on TV to them, in the cases where such recommendations were indicated, some trends were evident. According to the children's perceptions, parents recommend a product advertised on television to their children in the following instances:

- They believe the child will like the product (Q07: $25 \%$ of the respondents agreed or strongly agreed with this statement).

- It is for the child's own good (Q06: only 19\% agreed or strongly agreed with this statement).

- They want the child to try it (Q08: 55\% disagreed or strongly disagreed with this statement).

- Forty eight percent of the respondents disagreed or strongly disagreed with the statement that parents recommend a product because it is for the parents' own good (Q10).

It should be noted that the responses to the above questions did not relate to specific products or services. It is surmised that the results for possible future studies in which respondents' perceptions regarding their parents' motivations for recommending specific products to them will differ from the above-mentioned results.

Children's perceptions of the value of their parents' efforts to use television advertisements to 


\section{make a positive contribution to their consumer socialisation}

More than one-third of the respondents disagreed with the statement that they know why their parents recommend a product advertised on TV to them. Almost $27 \%$, however, believe they know why their parents recommend certain products (Q11). The majority of the children $(45,7 \%)$ indicated that they do not want products recommended to them by their parents (Q12). On the basis of the responses to the latter two statements, it can be concluded that the respondents do not value their parents' efforts to socialise them on consumer issues via television advertisements very highly.

\section{CONCLUSION}

The execution and results of this exploratory study confirm that it is a challenging task to research children. Marketers and researchers who wish to get "inside children's heads" should note that today's children are completely different from children of, say, ten years ago. According to Liebeck (1998), children are now more knowledgeable - they have increased access to information and a greater knowledge and understanding of today's issues. They are truly the Internet generation, and get their news and information primarily from television. Today's children also have disposable cash and visit multiple store formats every month. They understand the marketing and advertising campaigns presented to them. They are, however, rooted to home - their family is still their most important social group. The results indicate that television advertisements open up many opportunities for parents to educate their children on matters relating to marketing and other consumer issues.

This study stresses the need for future research in various fields to be conducted in the South African context. For example, the role of salespeople in the retail environment and the school as socialisation agents could fruitfully be studied. The literature study revealed that not a single study has been conducted to date in South Africa to investigate the role of retailers in educating young consumers. The positive assistance given by the secondary school sector in this research should be utilised by marketing and consumer science researchers in order to add new insights to the existing body of knowledge in this vibrant field. Understanding how children become socialised to function as consumers is important not only from a managerial or marketing perspective, but also from a societal, technological and cultural perspective where issues such as single-parent families, drug abuse and the Internet require the attention of researchers. Future research could also focus on cross-cultural marketing aspects regarding the consumer socialisation of children.

\section{REFERENCES}

ACUFF, D. 1997. What kids buy and why: the psychology of marketing to kids. New York. Free Press.

BLACKWELL, R, MINIARD, P \& ENGEL, J. 2001. Consumer Behaviour. $9^{\text {th }}$ ed. New York. Harcourt.

BURNS, A \& BUSH, R. 1998. Marketing Research. New Jersey. Prentice Hall.

CARDWELL-GARDNER, T \& BENNETT, JA. 1999. Television advertising to young children: an exploratory study. Proceedings of the 1999 IMM Marketing Educators Conference, September.

CARLSON, L \& GROSSBART, S. 1994. Family communication patterns and marketplace motivations, attitudes, and behaviours of children and mothers. Journal of Consumer Affairs 28(1): 25-54.

CARLSON, L, LACZNIAK, R \& WALSH, A. 2001. Socializing children about television: an intergenerational study. Journal of the Academy of Marketing Science 29(3): 276-288.

COOPER, D \& SCHINDLER, P. 1998. Business Research Methods. $6^{\text {th }}$ ed. New York. McGraw Hill.

DE VOS, A. 1998. Research at Grass Roots. Pretoria. Van Schaik.

ELLIOT, S. 2000. The effect of television advertisements on children's attempts to influence parental purchases. Unpublished Honours script. Pretoria. University of Pretoria.

ENGEL, J, BLACKWELL, R \& MINIARD, PW. 1995. Consumer Behavior. $8^{\text {th }}$ ed. Florida. Harcourt Brace College Publishers.

GEARY, J. 1999. Childhood's end? Time August 2:50.

GORN, G \& FLORSHEIM, R. 1985. The effects of commercials for adult products on children. Journal of Consumer Research 11:962-967.

HAIR, J, ANDERSON, R, TATHAM, R and BLACK, W. 1998. Multivariate data analysis. $5^{\text {th }}$ ed. New Jersey. Prentice-Hall. HAMILTON, J, MCLVEEN, H \& STRUGNELL, C. 2000. Educating young consumers - a food choice model. Journal of Consumer Studies and Home Economics 24(2):113-123.

HAWKINS, D, BEST, R \& CONEY, K. 2001. Consumer Behaviour. Building Marketing Strategy. $8^{\text {th }}$ ed. Boston. McGraw-Hill.

HEMPEL, D. 1974. Family buying decisions: a cross-cultural perspective. Journal of Marketing Research 10:295-302.

ISLER, L, POPPER, E \& WARD, S. 1987. Children's purchase requests and parental responses: results from a diary study. Journal of Advertising Research October: 28-39.

JOHN, DR. 1999. Consumer socialization of children: a retrospective look at 25 years of research. Journal of Consumer Research 26(3): 183-237.

KOENDERMAN, T. 2001. Marketing: catch 'em young. $\mathrm{Fi}$ nancial Mail June: 85.

LIEBECK, L. 1998. The customer connection: children under 13. Discount Store News October:55-57.

MACKLIN, C. 1987. Preschoolers' understanding of the informational function of television advertising. Journal of Consumer Research 14: 229-239.

McGEE, T. 1997. Getting inside kids' heads. American Demographics 19(1): 53-57.

MCGREGOR, S. 1999. Socializing consumers in a global marketplace. Journal of Consumer Studies and Home Economics 23(1): 37-45.

MCNEAL, JU. 1973. An Introduction to Consumer Behaviour. New York. Wiley.

MCNEAL, JU. 1993. Born to shop. Children's shopping patterns. American Demographics 15(6): 34-39.

MCNEAL, JU \& YEH, C. 1993. A cross-cultural study of children's consumer socialization in Hong Kong, New Zealand, Taiwan, and the United Nations. Asia Pacific Journal of Marketing and Logistics 5(3): 56-69.

MCNEAL, JU.\& JI, M. 1999. Chinese children as consumers: an analysis of their product information sources. Journal of Consumer Marketing 16(4): 345-364.

MEYER, T. 1987. How black kids see TV commercials. Journal of Advertising Research 18:51-85.

MULROONEY, B. 1999. Today's kids, today's megaspenders. Marketing Mix September: 26-33. 
NUNNALY, J. 1978. Psychometric Theory. New York. Mcgraw-Hill.

NORTH, EJ. 1987. Multistapnavorsing oor kinders in reklame. Unpublished DCom Dissertation. Pretoria. University of South Africa.

NORUM, P \& SCROGIN, J. 1996. Consumer complaint behaviour in the children's wear market in the US. Journal of Consumer Studies and Home Economics 20:363-375

ROEDDER, D. 1981. Age differences in children's responses

to television advertising. Journal of Marketing Research 8:144-153.

STIPP, H. 1988. Children as consumers. American Demographics 10(2): 26-33.
SHETH, J, MITTAL, B \& NEWMAN, B. 1999. Customer behavior: consumer behavior and beyond. New York. Dryden Press.

TV ADVERTISING DOES NOT INCREASE CHILDREN'S DEMANDS, SAYA NEW EU SURVEY. 2001. NOP Solutions. http://www.adassoc.org.uk/press/press65.html. Accessed 18/08/2001.

WARD, S. 1974. Consumer socialization. Journal of Consumer Research 1 (September): 1-14.

YAVAS, U \& ABDUL-GADER, A. 1993. Impact of TV commercials on Saudi children's purchase behaviour. Marketing Intelligence and Planning 11(2):37-43. 